Впадимир Бошковић

Универзитет Принстон

Њу Џерзи, САД
821.163 .41 .09 Димитријевић

305-055.2

\section{Јелена Димитријевић у контексту: ране феминисткиње и путописци Југоисточне Европе}

Крајем деветнаестог и почетком двадесетог века, на ширем простору Османског царства увелико захваћеног процесом одумирања, појављује се низ списатељица комплексне и фасцинантне литерарне субјективности. Мој рад се фокусира, поред Јелене Димитријевић, на Зејнеб Хануму, Халиде Едиб и Димитру Вака-Браун. Ове списатељице, као и Јелена Димитријевић, својим путописима доводе у питање доминантне жанровске, родне и националне дискурзивне моделе. Хибридна природа њиховог писања, њихов „искрени национализам и искрени космополитизам“, елузивни хомоеротицизам, иронија, мимикрија и родна маскарада у њиховим текстовима, њихова постколонијална песпектива све то представља окружење које погодује настанку транснационалних и трансрегионалних идентитета. Настојим да покажем како потреба ових жена да премошћују физичке, културне и симболичке просторе може да се интерпретира као трајни допринос редефинисању доминантне националне културне географије.

Кључне речи: Јелена Димитријевић, национализам, феминизам, транснационалност, постколонијалност, Зејнеб Ханума, Халиде Едиб, Димитра Вака-Браун 

савремена издања и привлаче шире интересовање научне и књижевне јавности, њена „маргиналност“ почиње све мање да се односи на позицију у српском књижевном канону, а све више на њену усамљеност у српској књижевној историји и критици тога времена. У међународним оквирима, међутим, Јелена Димитријевић се појављује као један од гласова у већој скупини списатељица на ширем простору Југоисточне Европе с почетка двадесетог века, са сличним тематским, идеолошким и књижевним карактеристикама. У овој презентацији усредсредићу ce на путописе о харемима из пера̂ османско-француске списатељице Зејнеб Хануме (Zeyneb Hanım), грчко-америчке списатељице Димитре Вака-Браун (Demetra Vaka Brown), и турске списатељице Халиде Едиб (Halide Edib Adivar).

Зејнеб Ханума ${ }^{1}$ представља занимљив случај за књижевну историју. Zeyneb Hanım је псеудоним Хатиџе Зенур (Hatice Zennur), кћери османског министра иностраних послова Нури-бега (Nuri Веу), која је постала позната, и недуго затим и озлоглашена, по томе што се под именом Зејнеб појавила у роману Пјера Лотија (Pierre Loti) Разочаране (1906). Роман описује појаву честу међу образованим турским женама у то време: док је западно

1 Турска имена пре Закона о презимену из 1934. навођена су традиционално, као комбинација личног имена и надимка или почасне титуле „ханум(а)“, „бег“, „паша“ и сл., без навођења породичног имена.

образовање, надахнуто либералним идејама, доносило престиж кћерима угледних турских породица, њихова будућност обично им је носила договорене бракове и живот у полигамним заједницама, фрустрацију и разочарање. По избијању скандала Зејнеб је са својом сестром одлучила да се склони у Француску. Неколико година касније објавила је књигу, одговор на Лотијев роман под насловом A Turkish Woman's European Impressions (1913). У тој књизи, својеврсној књижевној освети Лотију, описује свој „пут у слободу“, износи у јавност своје слике без вела у модерним салонима, али и своје постепено разочарање Француском и западним начином живота, оним што је она схватала као свеопште лицемерје и поремећен систем вредности. Тако је Зејнеб Ханум у својој књизи заменила оријентализам окцидентализмом и на крају одлучила да се врати у Турску.

О Зејнеб Хануми и њеној сестри дискутује Јелена Димитријевић у Писмима из Солуна као „Нури Бегов[им] кћери[ма]“, за које њена саговорница каже да су „Туркиње са француском крви“ и да Зејнеб, која се удала за пољског племића, „за Турчина није ни била“. ${ }^{2}$ Ова тематика очито је голицала Јелену Димитријевић довољно да напише читав роман, Нове (1912), у истом тематском кључу и пратећи Лотијев мемоарско-епистоларни књижевни поступак. Њен роман представља оригиналан одговор на дилеме и сукобе представљене у Лотијевом и Зејнеб Ханумином тексту. Граница фантазије и искуства и код ње је довољно варљива, да се јасно уочавају везе између описа стварних жена у Писмима из Солуна, и ликова у роману. Поигравање убедљивим и вероватним, књижевним и стварним, маскарада рода и жеље, пружа богат материјал за књижевну анализу. ${ }^{3}$

Димитра Вака-Браун, Цариграђанка грчке народности која је рано емигрирала у Сједињене Државе, била је ангажована од листова у којима је радила као експерт за регионалну политику

2 Јелена Димитријевић, Писма из Солуна (Лозница: Карпос, 2008), 74

3 Уп. Биљана Дојчиновић, „Чаробни сан Истока: Стварност у роману Нове Јелене Димитријевић“, Научни састанак слависта у Вукове дане, 36/2 (2007), 279-286; Владимир Ђурић, „Између l'image и le mirage: статус француске културе у роману Нове и Писмима из Солуна Јелене Димитријевић“, Књиженство 2, (2012) http:// www.knjizenstvo.rs/magazine.php?text=51 (преузето 20. 02. 2017). 
и објавила неколико књига о Југоисточној Европи, од којих су за овај рад најзанимљивије Haremlik (1909), The Child of Orient (1914) и The Unveiled Ladies of Stamboul (1923). Оне претежно описују њено детињство и рану младост у цариградским харемима, али и носталгичну испреплетаност њених успомена са текућом политичком и друштвеном стварношћу у Турској. Осим тога, ВакаБраун је пропутовала и балканске земље, објавивши занимљив путопис The Heart of the Balkans (1917), који свакако завређује пажњу српских истраживача. Вака-Браун је експлицитна у свом напору да донесе непристрасне извештаје; њени описи харема настоје да нормализују и доместификују алтернативни поглед на свет, описујући хареме као идеализован простор луксуза и уживања. Карактеристично, једна од њених првих прича која описује хармоничне породичне односе у полигамној заједници, укључена у нешто измењеном облику у Haremlik, била је најпре одбијена од издавача, који јој је наводно рекао да ће читаоци, „људи који иду у цркву и не воле мохамеданске обичаје“, таквом причом бити „згрожени“.4

Најзад, Халиде Едиб је ватрена турска патриоткиња која у својим књигама луцидно објашњава позицију турске државе и проблеме с којима се историјски суочава турски народ. За разлику од осталих списатељица које се овде помињу, њени текстови никад нису били „заборављени“ и њена позиција у канону турске књижевности је осигурана, добрим делом и стога што је постала чинилац у доминантним политичким и културним националним организацијама. Због своје политичке активности нашла се на удару како Великог муфтије цариградског, који је против ње издао фетву, тако и британске владе, због својих запаљивих јавних говора против британске окупације. Зато је 1919. године пребегла у Француску. За ову презентацију релевантни су њени Мемоари (1926), написани и објављени на енглеском. Књига је подељена на два дела, од којих први описује њено детињство и младост у харему, а други њен метафорички излазак из харема, традиционално „женске“ сфере, и улазак у јавни живот. Ова књига на тај начин представља

4 Reina Lewis, Rethinking Orientalism: Women, Travel and the Ottoman Harem (London and New York: Tauris, 2004), 30. метафоричку феминистичку апропријацију доминантно мушког простора и аутоетнографски приказ женске еманципације у Турској.

Заједничко овим списатељицама је, јасно, да су припадале првом таласу феминизма, борећи се, свака према својим могућностима, за окончање мушке доминације над женама. Један од њихових најпречих начина за остварење тог циља био је директно освајање физичког простора: путовање. Жена која путује, пише, извештава, постаје културно-политички агенс чак и ако није у позицији да контролише дискурзивне поступке мушке књижевности које користи; истовремено, као известилац из харема, она користи егзотичну и примамљиву тему о којој говори из привилеговане позиције, као сведок истине до које само она може да допре - освајајући тако не само сопствени глас, него и позицију у мушкој књижевној историји.

Даље тачке додира списатељица о којима говорим укључују значај новинарства и књижевних магазина, не само за ширење литерарног материјала и развој њихових књижевних укуса, већ и као средство повезивања, упознавања и међусобне сарадње. Часописи с насловима као Жена/Гvvі́/Kadın, Српкиња/ Гркиња, Женски свет/Kadınlar Dünyası итд., оснивани су у свим земљама Југоисточне Европе. Стил репортерског извештавања, с друге стране, често преузима место аутобиографског мемоара и уводи социјално ангажоване нараторке са јасном политичком, идеолошком и културном самоидентификацијом. Светлана Томић је тако показала како су Јеленина Писма из Солуна састављена као феминистички одговор на Нушићеве извештаје објављене у Политици. ${ }^{5}$ С друге стране, Халиде Едиб, иако је насловила свој текст Mемоари, у његовом другом делу често дуже извештава о актуелним политичким збивањима него о сопственој улози у њима. (Узгред, женски лист чију је припрему Ђулистан Исмет најавила Јелени Димитријевић у интервјуу који је остао сачуван у Писмима из Солуна ${ }^{6}$ вероватно је Kadın, који је излазио у Солуну од октобра 1908. до маја 1909. године.)

5 Светлана Томић, „Две врсте Писама из Солуна: Феминистичко истраживачко новинарство Јелене J. Димитријевић наспрам непоузданог извештавања Бранислава Нушића“, Нови израз, 55-56 (2012): 154-169.

6 Јелена Димитријевић, Писма из Солуна (Лозница: Карпос, 2008), 43. 
Још један важан простор њиховог сусрета јесу западне мисионарске школе: на територији Османског царства у том периоду било их је преко четири стотине.7 У сваком месту у које би дошла, Јелена Димитријевић би обишла локални француски или амерички институт; и њена саговорница Ђулистан Исмет поносно истиче како је „прва Туркиња са дипломом“, 8 тачније прва муслиманка која је завршила Амерички колеџ за девојке у Истанбулу (као део образовне институције која ће касније прерасти у данашњи Босфорски универзитет ${ }^{9}$. Халиде Едиб такође је дипломирала на овој школи. Ове институције служиле су као центри западног образовања за локалну елиту, осниване и финансиране од религијских и секуларних филантропских друштава.

Најинтересантије паралеле између ових списатељица, међутим, тичу се њиховог културног контекста и националног идентитета. Већ само навођење њихових националности и језика није једноставан задатак: Зејнеб Ханума је Туркиња француског порекла и образовања која је објавила своју једину књигу на енглеском. Димитра Вака Браун је Гркиња рођена на Принчевским острвима надомак Цариграда која је са седамнаест година емигрирала у Сједињене Државе, самоидентификујући се као Византинка (што вероватно треба да схватимо као Ромејка, термин који и данас користе Грци који живе у Турској). Њено „освајање језика“ може се пратити на насловним странама њених књига, на којој се име њеног супруга, новинара Кенета Брауна (Kenneth Brown), као коаутора, појављује све мање и мање од наслова до наслова, док на крају потпуно не нестане. Халиде Едиб сматра се једном од оснивачица турског национализма, али она је такође била западно образована полиглоткиња која је своје књиге о Турској, укључујући и своју аутобиографију о харему, написала на енглеском током свог боравка у Великој Британији и Америци. Интересантно је да је Едиб инсистирала да издавач не мења и не коригује њене енглеске изразе;

7 Уп. İlknur Polat Haydaroğlu, Osmanh Imparatorluğu’nda yabancı okullar (Ankara: Kültür Bakanlığı, 1990).

8 Јелена Димитријевић, нав. дело, 40 .

9 Mary Mills Patrick, A Bosphorus Adventure: Istanbul (Constantinople) Woman's College 1871-1924, (Stanford, London: Stanford University Press, Humphrey Milford, Oxford University Press, 1934); Fatma Acun. "Arnavutköy Amerikan Kız Koleji mezunlan ve meshurları", Cumhuriyet Tarihi Arastormaları Dergisi 11/2 (2015): 417-442. због тога њен језик често зазвучи „острањено“, не одговарајући енглеској идиоматичности. Јелена Димитријевић је, као што је познато, била франкофона и писала песме на француском, док су њена Писма из Ниша и Солуна, а нарочито ова прва, до те мере прошарана не само турцизмима већ и читавим турским цитатима да се у појединим пасусима скоро може говорити о макаронском, српско-турском тексту. ${ }^{10}$

Питање културног одређења ових ауторки заиста је најсложенија тема овог кратког прегледа. Склон сам да њихово писање сместим у османски постколонијални контекст, иако такво позиционирање захтева одређене резерве и серију додатних објашњења за које овде нема простора, али за које читаоце упућујем на мој увод у енглески превод Писама из Солуна. ${ }^{11}$ Укратко, сматрам да се за текстове о којима говорим може применити методологија коју је развила Мери Луиз Прат (Mary Louise Pratt) у својим студијама латиноамеричких култура. У том кључу, Југоисточна Европа се може разумети као „зона контакта“, захваћена процесом транскултурације, односно колективне трансформације културе под притиском доминантног економског и војног присуства Запада.

Из угла културног центра, транскултурирана субјекткиња је увек-само подражавалац доминантне цивилизације, чак и кад је осећа као своју; она је глумица и извођач културе, а „аутентични“ културни носилац је њена публика и критичар. Карактеристичан је одломак из Харемлика Димитре Вака-Браун, где нараторка описује дијалог са својом пријатељицом Хулме, алудирајући на Лотија, у поглављу под насловом „Хулме Ханум, незадовољна“:

„Жао ми је што сам одгајена као западна жена“.

„Али ти то ниси“, рекла сам. „Ти си мање западњакиња од свих муслиманки које сам срела. Због чега мислиш да си као ми?“

„Јер су ме, млада ханум, одгајили странци. Говорим енглески, француски и немачки једнако добро као и свој

10 В. нпр. Јелена Димитријевић Ј. Димитријевић, Писма из Ниша о харемима (Београд: Парна радикална штампарија, 1897), 23, 118-120, и другде.

11 Vladimir Boskovic, "Critical Introduction“, y Jelena Dimitrijevic, Letters from Salonika, trans. V. Boskovic, (Piscataway: Gorgias Press, 2017). 
језик, и познајем више ваше књижевности него сопствене. (...) Образују нас и уче нас да мислимо као што мислите ви, жене са запада, али будући ток наших живота толико нас разликује. (...) Волела бих да никад, никад нисам сазнала.“12

Ова сцена представља дефиницију (пост)колонијалне мимикрије, усађена као mise en abyme у књигу американизоване новинарке. Вака-Браун је и сама транскултурирани субјект, она постоји на више места у више својстава: она је Американка кад извештава за новине и грчка патриоткиња кад интервјуише грчког краља. Она, међутим, ту чињеницу брижљиво искључује из свог наратива; уместо тога, користи своју привилеговану позицију наратора да наступи као судија, штавише да искључи могућност да Друга може да стекне други идентитет осим намењеног јој. Хулме Ханума може да изгледа, да се понаша, чак и да се осећа као западњакиња, али никада не може бити западњакиња. Успешна мимикрија нараторке тако јој омогућава да реафирмише сопствени литерарни идентитет, кроз нарацију разлике и хибридизације. ${ }^{13}$

Случај Зејнеб Хануме свакако је најкомпликованији од свих овде наведених: њено извођење и поигравање идентитетима укључује комплексну мрежу субјеката, стварних, имагинарних, и оних негде између. У својој књизи Зејнеб Ханума потенцира свој турски идентитет и ниједном речју не помиње своје француске претке. С друге стране, у једном тексту у листу Фигаро из 1909, објављеном на насловној страни, покушава да објасни „шта се стварно догодило“ и да разграничи истину и фантазију у Лотијевом роману. ${ }^{14}$ У овом тексту, тако, открива да је у Француској узела породично име свог деде, маркиза Блосе де Шатонеф (Blosset de Châteauneuf), Француза који је прешао на ислам. Тако Зејнеб Ханума постоји као сасвим меркуријална фигура, чији је идентитет далеко

12 Demetra Vaka Brown, Haremlik: Some Pages from the Life of Turkish Women (Boston \& New York: Houghton Mifflin 1909), 136-137, (превод В.Б).

${ }_{13}$ Уп. Nilüfer Göle, The Forbidden Modern: Civilization and Veiling.Critical Perspectives on Women and Gender (Ann Arbor, MI: University of Michigan Press, 1996).

14 Hadidjé-Zennour, “La Verité vraie sur les 'Désenchantées", Le Figaro (21. децембар 1909).

162 комплекснији од транснационалних лојалности њене „реалне“ или „историјске“ основе, Хатиџе Зенур. ${ }^{15}$

Историја женског харемског путописа дубоко је укорењена у историју колонијализма. Она почиње у осамнаестом веку са Леди Мери Монтегју (Lady Mary Montagu, или како ју је звао Светомир Николајевић, Леди Монтегијева) ${ }^{16}$ и убрзо постаје популаран жанр, да би до 190о. године број објављених путописа експоненцијално растао. Према Били Мелман (Billie Melman) (1995), женско харемско писање пратило је социјалне промене у западним друштвима: док је аристократкиња Монтегју видела харем као место удобног и слободног живота, а хиџаб као згодан начин отменим дамама за безбедно варање мужева, дотле је викторијанско доба донело представе харема као места очувања средњекласних породичних вредности, марљивости и брачних врлина. Тако ће и харемске списатељице с почетка двадесетог века, када на њих дође ред, видети харем како поприште борбе за женску еманципацију. Оне ће се често без резерви залагати за укидање вела као средства мушке опресије (Димитријевић), или, обратно, романтизовати и егзотизовати хиџаб као носталгичан симбол „старих времена“ која се неповратно губе пред модернизацијом која брише локалне културне традиције (Вака-Браун).

У том смислу, списатељице о којима говорим могу се историјски наратизовати: Јелена Димитријевић описује харем очима субјекта у оба значења те речи, прво у својству кћери султанове поданице, „робиње“ како то често истиче, ${ }^{17}$ а затим као сусетка муслиманских жена, која са самопоуздањем новоизграђене српске нације одлучно стаје на страну модерности а против вела Зејнеб Ханума је лиминални случај, књижевно заглављена између двеју култура чије разлике и когнитивне дисонанце није у стању да превазиђе, додатно закомпликоване транскултурацијом османског високог друштва коме је припадала, да би коначно одбранила

15 Детаљније о овом замешатељству код Луис, нав. дело, 20-24.

16 В. и К. Konuk, "Ethnomasquerade in Ottoman-European Encounters: Reenacting Lady Mary Wortley Montagu," Criticism 46/3 (2004), 393-414; M. Yeğenoğlu, Colonial Fantasies: Towards a Feminist Reading of Orientalism (Cambridge: Cambridge University Press, 1998)

17 Нпр. Јелена Димитријевић, Писма из Солуна, нав. издање, 52. 
свој субјективитет окцидентализмом и повратком у безбедност бинарних опозиција. Халиде Едиб је сведок промене која се десила у самој Турској, у зрелијој фази транскултурације у којој је појам турске националне културе коначно редефинисан и формулисан; она је себе самоодредила као западњакињу, одрекавши се харема (карактеристично, она замера Димитри Вака-Браун чак и наслов њене књиге, Харемлик, тврдећи да та реч не постоји у турском. ${ }^{18}$ Најзад, Димитра Вака-Браун описује егзотичан и доместификован харем из својих успомена, умногоме прећуткујући или релативизујући стварне проблеме турских жена.

На крају, остао сам дужан да додам неколико речи о национализму Јелене Димитријевић и њених постосманских сапутница. У текућој критици, жене-путописци се често схватају као примери женског отпора не само патријархалној контроли женског простора, већ и женског отпора доминантном националном и националистичком дискурсу. Пут у харем, да употребим речи Невене Ивановић, ${ }^{19}$ води од позиције „беле жене, колонизаторке“, која полази да ослободи „оријенталне“ жене; али тај пут доводи до њеног губитка центра у матичној култури, и до заборава. ${ }^{20}$

Треба, међутим, узети у обзир да је културна топографија у текстовима Јелене Димитријевић имала друкчију семантику него данас, и да у патриотизму ових списатељица није било контрадикције. У необјављеној рукописној белешци која се данас чува у Народној библиотеци, насловљеној „Моја исповест“, Јелена Димитријевић карактеристично пише:

18 В. Луис, нав. дело, 109 са референцама.

19 Невена Ивановић, „Запоседање другог и манипулација 'женским писмом““, P.E.Ч. 59/5, (2000): 214-216.

20 Уп. и V. Boskovic, "Unveiling the Male Empires: Jelena Dimitrijević in Thessaloniki", Balkan Studies, 50, (2015): 129-137. Важно је напоменути да Јелена Димитријевић, нарочито у каснијим текстовима, наступа са изразито друкчијих позиција, истичући своју припадност „малом народу“ и избегавајући да се идентификује са западним путницама. Њу сиромаштво египатских фелаха подсећа на српска села, а икона у коптском домаћинству на њену девојачку славу (Јелена Димитријевић, Седам мора и три океана: путем око света (Београд: Државна штампарија Краљевине Југославије, 1940), 73-78, 199-200). Посебно је карактеристична епизода са традиционалним сабљама на базару у Дамаску, које је подсећају на трауматична искуства османског терора коме је била сведок у детињству: „Запазила сам, да ниједна турискиња није ни погледала ове сабље, а камо ли да је на њима нешто 'видела"“(Ibid., 365).
Православна сам, најправославнија која постоји; а у Египту сам се осећала мусломанка, у Индији сад Браманка а сад Париа; у Кини Будискиња; у Јапану Шинто; на неким острвима Тихога Океана паганка; у Америци Хришћанка али протестанске вере. А // ипак, увек, остајала сам православна, најправославнија која постоји. (...) Народност нисам мењала. Свуд сам била оно што су били и што су моји. Јер то се не може променити друкчије до кад би се источила сва ова крв из мојих жила, а уточила се друга... ${ }^{21}$

Потреба Јелене Димитријевић да „исповеди“ свој религијски универзализам потврђује да је осећала извесну тензију између свог космополитизма с једне стране, и свог религиозног и етничког идентитета са друге; али овај одломак показује такође и да је сматрала да је њен национални идентитет савршено способан да укључи и апсорбује њене универзалистичке и пантеистичке импулсе, што је управо супротно данашњој националистичкој прагматици. Као и код других списатељица о којима сам говорио, национализам Јелене Димитријевић заснован је на социјалним димензијама националних револуција, где је нагласак стављен на ослобођење од феудалне репресије, и где је центрирање још увек политичко а не етничко, а просветитељски наратив доминантан.

Како се семантичка мрежа европских национализама постепено променила заједно са својим социокултурним контекстима, тако је програм Јелене Димитријевић постао непримењив и неускладив са новим идентитетским и културним политикама. Другим речима, Јелена Димитријевић није искључила себе из своје културе, већ је култура којој је припадала променила курс и исцрпла свој ослобађајући потенцијал, поставши носилац нове опресије. Јеленин слободан, космополитски дух није више имао места у њој.

21 P 549/III, 4v-6r, Народна библиотека Србије, Архив Јелене Димитријевић Одељење посебних фондова). 


\section{ПИТЕРАТУРА}

Acun, Fatma. "Arnavutköy Amerikan Kız Koleji mezunları ve meşhurları", Cumhuriyet Tarihi Araștormaları Dergisi 11/2, (2015): 417-442.

Boskovic, Vladimir. "Unveiling the Male Empires: Jelena Dimitrijević in Thessaloniki,“ Balkan Studies 50, (2015):129-137.

Boskovic, Vladimir. "Critical Introduction“. y Jelena Dimitrijevic, Letters from Salonika, прев. V. Boskovic, (у штампи). Piscataway: Gorgias Press, 2017.

Vaka Brown, Demetra. Haremlik: Some Pages from the Life of Turkish Women. Boston \& New York: Houghton Mifflin, 1909.

Vaka Brown, Demetra. The Child of Orient. Boston \& New York: Houghton Mifflin, 1914

Vaka Brown, Demetra. The Heart of the Balkans. Boston \& New York: Houghton Mifflin, 1917.

Vaka Brown, Demetra. The Unveiled Ladies of Stamboul. Boston \& New York: Houghton Mifflin, 1923.

Göle, Nilüfer. The Forbidden Modern: Civilization and Veiling. Critical Perspectives on Women and Gender. Ann Arbor, MI: University of Michigan Press, 1996.

Димитријевић, Јелена. Писма из Ниша о харемима. Београд: Парна радикална штампарија, 1897. Савремено издање Београд: Дечје новине, 1986 прир. Слободанка Пековић, и Ниш: Просвета, 2003, прир. Јелена Јовановић (заједно са Ђул-Марикином прикажњом).

Димитријевић, Јелена. Седам мора и три океана: путем око света, Београд: Државна штампарија Краљевине Југославије, 1940. Савремено издање Београд: Лагуна 2016, прир. Биљана Дојчиновић.

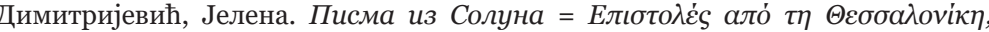
прир. и превео на грчки Владимир Бошковић и др., Лозница: Карпос, 2008. Оригинално издање у Српском књижевном гласнику 21/11-12, 22/1-8 (децембар 1908-април 1909), штампано као засебна књига Сарајево: И. Ђ. Ђурђевић, 1918.

Димитријевић, Јелена. Нове, прир. Биљана Дојчиновић. Београд: Службени гласник, 2012. Оригинално издање Београд: Српска књижевна задруга, 1912.

Дојчиновић, Биљана. „Чаробни сан Истока: Стварност у роману Нове Јелене Димитријевић“. Научни састанак слависта у Вукове дане 36/2, 2007: 279-286.

Ђурић, Владимир. „Између l’image и le mirage: статус француске културе у роману Нове и Писмима из Солуна Јелене Димитријевић“. Књиженство 2, 2012, http://www.knjizenstvo.rs/magazine.php?text=51 (преузето 20. 02. 2017).

Ђурић, Владимир. „Фикција и истина у роману Нове и Писмима из Солуна Јелене Димитријевић“. У Савремена проучавања језика и књижевности књ. 2, ред. М. Анђелковић, 535-544. Крагујевац: Филолошко-уметнички факултет 2014

Edib Adıvar, Halide. Memoirs of Halide Edib. New York \& London: Century. 1926 Савремено издање: Piscataway, NJ: Gorgias Press, 2005.

Hadidjé-Zennour. "La Verité vraie sur les 'Désenchantées"“. Le Figaro (21. децембар), 1909.
Hanoum, Zeyneb. A Turkish Woman's European Impressions. Philadelphia: J. B. Lippincott, 1913. Савремено издање Piscataway, NJ: Gorgias Press, 2004

Ивановић, Невена. „Запоседање другог и манипулација 'женским писмом'“, P.E.Ч. 59/5, 2000: 199-243

Yeğenoğlu, Meyda. Colonial Fantasies: Towards a Feminist Reading of Orientalism. Cambridge: Cambridge University Press, 1998.

Konuk, Kader. "Ethnomasquerade in Ottoman-European Encounters: Reenacting Lady Mary Wortley Montagu“. Criticism 46/3, 2004: 393-414.

Loti, Pierre. Disenchanted (Désenchantées): A Romance of Harem Life. енглески прев. C. Bell. New York: Macmillan. Оригинално издање 1906.

Lewis, Reina. Rethinking Orientalism: Women, Travel and the Ottoman Harem. London and New York: Tauris. 2004.

Melman, Billie. Women's Orients: English Women and the Middle East 1718-1918. Ann Arbor: University of Michigan Press, 1995.

Patrick, Mary Mills. A Bosphorus Adventure: Istanbul (Constantinople) Woman's College 1871-1924. Stenford, London: Stanford University Press; Humphrey Milford; Oxford University Press, 1934.

Pratt, Mary Louise. Imperial Eyes: Travel Writing and Transculturation. London Routledge, 1992.

Томић, Светлана. „Две врсте Писама из Солуна: Феминистичко истраживачко новинарство Јелене Ј. Димитријевић наспрам непоуданог извештавања Бранислава Нушића“. Нови израз, 55-56 (2012): 154-169.

Haydaroğlu, İlknur Polat. Osmanlı Imparatorluğu’nda yabancı okullar. Ankara: Kültür Bakanlığı, 1990.

\section{АРХИВСКИ МАТЕРИЈАЛ}

P = Народна библиотека Србије, Архив Јелене Димитријевић (Одељење посебних фондова) 
Jelena Dimitrijević in context: early feminist travel writers of southeastern Europe

Towards the turn of the last century, the wider space of the Ottoman Empire gave rise to a number of female writers characterized by a complex and fascinating literary subjectivity. My paper focuses, in addition to Jelena Dimitrijević, on Zeyneb Hanoum, Halide Edib, and Demetra Vaka Brown. In their travel narratives, these writers, like Dimitrijević, question the dominant genre, gender, and national discoursive models. The hybrid nature of their writing, their "sincere nationalism and sincere cosmopolitism," elusive homoeroticism, irony, mimicry, and gender masquerade in their writing, their postcolonial perspective-all this creates a conductive environment for an emergence of transnational and transregional identities. I strive to show how the need of these women to traverse the physical, cultural, and symbolic spaces can be interpreted as a lasting contribution towards redefining the dominant national cultural geographies.

Keywords: Jelena Dimitrijević, nationalism, feminism, transnationalism, postcolonialism, Zeyneb Hanoum, Halide Edib, Demetra Vaka Brown

\section{Туркиње и турске теме у раној приповедној прози Јелене Димитријевић}

У својој раној књижевној фази, Јелена Димитријевић је Туркињама, односно, „турским темама“ посветила књигу поезије (Јеленине песме), роман (Нове), путописе (Писма из Ниша о харемима, Писма из Солуна) и три приповетке (Фати-султан, Сафи-ханум, Мејрем-ханум) Док су њена романескна и путописна дела углавном добро истражена, приповедна проза је остала готово непозната. Три поменуте приповетке (објављене обједињено у једној књизи 1907. године) биће предмет овог рада: о приповеци „Фати-Султан“ говориће се детаљно, док ће се на крају рада указати на садржај друге две приче како би се показала њихова тематско-мотивска сродност. Показаће се, сем културно-историјских, и књижевно-естетске вредности ране прозне фазе књижевног рада Јелене Димитријевић.

Кључне речи: рана проза, „турске теме“, Балкан 